4. Clapham A. The Role of the Individual in International Law. The European Journal of International Law. 2010. Vol. 21 № 1. P. 25-30.

5. Giorgetti C. Rethinking the Individual in International Law. Lewis \& Clark L. Rev. 2019. Vol 22. P. 1085-1149.

DOI https://doi.org/10.30525/978-9934-588-92-1-96

\title{
ІМПЛЕМЕНТАЦІЯ СТАНДАРТІВ ЗАХИСТУ ЕКОЛОГІЧНИХ ПРАВ ЛЮДИНИ, ЗАКРІПЛЕНИХ УГОДОЮ ПРО АСОЦІАЦІЮ МІЖ УКРАЇНОЮ ТА ЄС, В НАЦІОНАЛЬНЕ ПРАВО УКРАЇНИ
}

\author{
Лихогляд В. П. \\ аспірантка кафедри міжнародного права \\ Інститута міжнародних відносин \\ Київського національного університета імені Тараса Шевченка \\ м. Київ, Украӥна
}

Забезпечення прав людини екологічного спрямування, зазначених в Угоді про Асоціацію між Україною, з однієї сторони, та Європейським Союзом, Свропейським Співтовариством 3 атомної енергії і їхніми державами-членами, з іншої сторони є обов'язком держави, виконання якого означає, що Україна імплементує міжнародні стандарти екологічних прав людини.

Розділ 6 Угоди, «Навколишнє середовище», передбачає, що сторони співпрацюють щодо охорони навколишнього середовища, шляхом сприяння реалізації довгострокових цілей сталого розвитку. Стаття 361 Угоди зазначає, що кліматичні зміні є регіональними та глобальними проблемами навколишнього середовища. Стаття 365 стосується імплементації кліматичної політики, і відсилає нас до Додатку XXXI, який передбачає три основні напрямки роботи у сфері зміни клімату:

a) імплементацію Кіотського протоколу разом 3 критеріями його відповідності для повного запровадження кіотських механізмів;

б) розробку довгострокового плану дій щодо пом'якшення кліматичних змін та подальшої адаптації до них;

в) розробку та запровадження довгострокових заходів для скорочення викидів парникових газів [1].

Відповідно до Додатка XXX, Україна повинна адаптувати своє законодавство до більш ніж двох десятків директив та трьох 384 
регламентів Європейського Союзу у таких сферах, як: екологічне управління та інтеграція екологічної політики в інші галузеві політики, якість повітря, управління відходами та ресурсами, якість води та управління водними ресурсами, включаючи морське середовище, промислове забруднення та антропогенні загрози тощо. Всі ці заходи сприяють забезпеченню екологічних прав людини, як право на безпечне для життя і здоров'я довкілля [1].

Очікуваними результатами після такої адаптації повинні стати:

- Впровадження міжнародних стандартів у галузі збереження ресурсів, охорони навколишнього середовища, використання надр;

- Підвищення рівня екологічної безпеки;

- Реформа екологічної політики, відповідно до вимог acquis ЄC [2].

Щодо стану імплементації стандартів СС у сфері екологічних прав людини в українське законодавство, то Верховною Радою України було прийнято Закон України «Про оцінку впливу на навколишнє середовище», який надає можливість впровадити прогресивну, оновлену та проєвропейську модель оцінки впливу на навколишнє середовище відповідно до вимог Директиви 2011/92/ЄС щодо оцінки впливу деяких державних та приватних проєктів на навколишнє середовище [3]. У 2018 році прийнято Закон України «Про стратегічну екологічну оцінку», який враховує вимоги Протоколу про стратегічну екологічну оцінку та Директиви 2001/42/СС про оцінку впливу деяких планів і програм на навколишнє середовище [4]. Ці два закони дадуть суспільству та державі змогу отримувати найбільш вірогідну та точну інформацію про навколишнє середовище в Україні.

Також Верховна Рада України прийняла Закон України № 2047-VIII від 18 травня 2017 року «Про внесення змін до Закону України» Про питну воду та питне водопостачання», який створив базу для імплементації положень Директиви 98/83/ЄС про якість води, призначеної для споживання людиною та Директива 91/271/СС щодо очищення міських стічних вод [5]. Цей закон охороняє право людини на безпечну питну воду.

Задля імплементації норм Регламенту 842/2006/СС щодо деяких фторованих парникових газів та Регламенту 2037/2000/ЄС про речовини, що руйнують озоновий шар, 12.12.2019 року було прийнято Закон України «Про регулювання господарської діяльності 3 озоноруйнівними речовинами та фторованими парниковими газами». Він передбачає регулювання відносин щодо виробництва, імпорту, експорту, зберігання, використання, торгівлі та поводження 3 
озоноруйнівними речовинами, фторованими парниковими газами, товарами та обладнанням, які впливають на озоновий шар та загальний рівень глобального потепління. Тобто, з 2020 року введені заборони на використання контрольованих речовин, зокрема вуглеводів, заборони на ввезення обладнання, що працює 3 вуглеводнями, встановлено вимоги щодо моніторингу та перевірки витоку цих речовин, визначено зобов'язання щодо їх відновлення, регенерації та знищення, встановлено освітні та сертифікаційні вимоги до персоналу та компаній, а також встановлено норми поводження 3 фторованими парниковими газами [6]. Таким чином, це сприятиме охороні озонового шару та стане одним із кроків до запобігання зміні клімату.

Проте, багато ключових пунктів Плану заходів з виконання Угоди про асоціацію залишилось невиконаними. У 2016 році, на виконання положень Директиви 2003/4/СС мало бути прийнято законодавства щодо доступу до екологічної інформації та визначення уповноваженого органу (органів) у цій сфері, встановлення на практиці процедури доступу громадськості до екологічної інформації та відповідних винятків [7]. Однак, через відсутність будь-якого прогресу в цьому питанні, розширені права людини на доступ до екологічної інформації залишаються «не доступними» в Україні.

Так, досі не розроблений національний план розподілу квот на викиди парникових газів між установками. Не прийнято законопроєкт про водовідведення та очищення стічних вод населених пунктів. Відповідно, не проведено й оцінку вразливості підземних і поверхневих вод до забруднення нітратами із сільськогосподарських джерел, на вимогу Директиви 91/676/СС.

Не фіналізовано й систему моніторингу, звітності та верифікації викидів парникових газів, а також процедури консультацій з громадськістю, зокрема відсутня система управління базами даних системи моніторингу, звітності та верифікації викидів парникових газів [8].

Зокрема, у 2019 прострочені вимоги Угоди про асоціацію, які передбачали розроблення нормативно-правової бази для здійснення оцінки якості атмосферного повітря та заходів щодо його покращення відповідно до Директив 2008/50/ЄС, 2004/107/ЄС та 2004/42/ЄС [9].

Можна стверджувати, що в Україні $є$ законодавче підгрунтя для забезпечення сприятливого природного оточення для людини. Втім, у законодавстві, яку стосується сталого розвитку досі існує багато прогалин, неузгодженостей, суперечностей, адже стандарти захисту екологічних прав, закріплені в Угоді про асоціацію, досить часто імплементуються не в повному обсязі. Тому наша держава, враховуючи вищевказані пріоритети та принципи, має модернізувати екологічне 386 
законодавство шляхом його систематизації та приведення його у відповідність до європейських стандартів.

\section{Література:}

1. Угода про Асоціацію між Україною, 3 однієї сторони, та Європейським Союзом, Європейським співтовариством 3 атомної енергії і їхніми державами-членами, 3 іншої сторони //Офіц. вісн. України. 2014. № 75.

2. Environment. URL: https://eu-ua.org/en/environment___дата звернення: 19.10.2020).

3. Закон України «Про оцінку впливу на довкілля». URL: https://zakon.rada.gov.ua/laws/show/2059-19_(дата звернення: 19.10.2020).

4. Закон України «Про стратегічну екологічну оцінку». URL: https://zakon.rada.gov.ua/laws/show/2354-19 (дата звернення: 19.10.2020).

5. Закон України № 2047-VIII «Про внесення змін до Закону України «Про питну воду та питне водопостачання». URL: https://zakon.rada.gov.ua/laws/show/2047-19_(дата звернення: 19.10.2020).

6. Прийнято Закон «Про озоноруйнівні речовини та фторовані парникові гази». URL: https://iportal.rada.gov.ua/news/Novyny/ 185970.html (дата звернення: 19.10.2020).

7. Навколишнє природне середовище та цивільний захист. Стан виконання Угоди про асоціацію за 2016 рік. URL: https://pulse.euua.org/ua/streams/environment_(дата звернення: 19.10.2020).

8. Навколишнє природне середовище та цивільний захист. Стан виконання Угоди про асоціацію за 2018 рік. URL: https://pulse.euua.org/ua/streams/environment_(дата звернення: 19.10.2020).

9. Навколишнє природне середовище та цивільний захист. Стан виконання Угоди про асоціацію за 2019 рік. URL: https://pulse.euua.org/ua/streams/environment_(дата звернення: 19.10.2020). 